\title{
Meta-analysis of two approaches to Laparoscopic Adrenalectomy: lateral transperitoneal versus posterior retroperitoneal approach
}

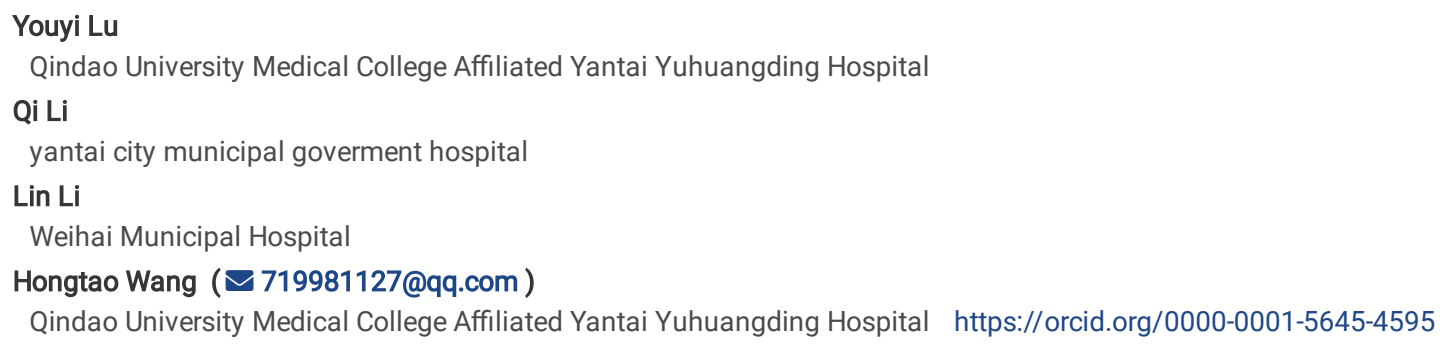

\section{Research article}

Keywords: transperitoneal, retroperitoneal, adrenalectomy

Posted Date: March 24th, 2020

DOI: https://doi.org/10.21203/rs.3.rs-18722/v1

License: () (1) This work is licensed under a Creative Commons Attribution 4.0 International License. Read Full License 


\section{Abstract}

Background:Even though many studies have reported comparisons of the lateral transperitoneal adrenalectomy (LTA)and posterior retroperitoneal adrenalectomy (PRA) approaches,the conclusions were inconsistent.This meta-analysis aims at a systematic assessment of LTA and PRA.

Methods:We searched MEDLINE, Pubmed, and Embase database and finally obtained 19 studies published since January 2009.Systematic review was conducted based on the Preferred Reporting Items for Systematic Reviews and Meta-analyses. RevMan 5.3(Cochrane Collaboration) was used for data analysis.

Results: 19 studies were included in the meta-analysis. The clinical characteristics of the 2 groups were similar(age, BMI, proportion of right sided, proportion of bilateral lesions, and previous abdominal surgery).There was slightly higher heterogeneity in proportion of male patients $(\mathrm{OR} 0.87,95 \% \mathrm{Cl} 0.78$ to $0.97, \mathrm{P}=$ 0.01 ) and size of the tumor (MD $0.62,95 \% \mathrm{Cl} 0.16$ to $1.08, \mathrm{P}=0.008)$. The results confirmed that the PRA group was superior to LTA group regarding shorter operative time (MD 17.54, $95 \% \mathrm{Cl} 9.67$ to $25.40, \mathrm{P}<0.0001$ ), lower estimated blood loss (MD $37.75,95 \% \mathrm{Cl} 18.08$ to $57.41, \mathrm{P}=0.0002$ ), shorter hospital stay (MD 1.19, $95 \% \mathrm{Cl} 0.76$ to $1.63, \mathrm{P}<0.00001)$ and shorter time to first oral intake(MD $0.48,95 \% \mathrm{Cl} 0.11$ to $0.86, \mathrm{P}=0.01)$. There were no statistically significant differences between LTA and PRA regarding overall complication(OR 1.37, 95\% $\mathrm{Cl} 0.96$ to 1.97, P = 0.08), conversion to open laparotomy (OR $1.16,95 \% \mathrm{Cl} 0.63$ to $2.16, \mathrm{P}=0.63$ ) or blood transfusion(OR $2.22,95 \% \mathrm{Cl} 0.51$ to $9.57, \mathrm{P}=0.28)$.

Conclusion:This meta-analysis suggests that PRA has more advantages over LTA,such as shorter operative time,lower estimated blood loss, shorter hospital stay and shorter time to first oral intake.And there were no statistically significance between LTA and PRA in terms of postoperative outcomes(total complications, conversion rates and blood transfusion).

\section{Introduction}

In the last decades,adrenalectomy has progressed from an operation to minimally invasive surgery ${ }^{[1]}$.Some patients require surgical treatment because of functional or suspected malignancy adrenal tumors ${ }^{[2]}$. Laparoscopic adrenalectomy is the preferred approach for removal of most adrenal tumors.Various studies demonstrated the safety and efficacy of laparoscopic technique.Among laparoscopic approaches,the lateral transperitoneal adrenalectomy (LTA) and the posterior retroperitoneal adrenalectomy (PRA) are common surgical procedures for the treatment of adrenal tumors.

Since first reported in $1992^{[3]}$, LTA have been widely increased. LTA offers a wide working space for removal of larger adrenal tumors ${ }^{[4]}$. Conversely, PRA, first reported in 1995, can provides direct access to the adrenal tumor and avoids potential injury to the intra-abdominal organs. ${ }^{[5]}$ Moreover, in PRA, adhesions can be avoided in patients with previous abdominal interventions, and the surgeon can treat bilateral tumors simultaneously, without changing position ${ }^{[6]}$. Currently, selection of surgical modalities for adrenal require a comprehensive consideration of the experience of surgeon,anatomical location and size of tumor ${ }^{[7]}$.

Even though many studies have reported comparisons of the two laparoscopic approaches,the conclusions were inconsistent. This meta-analysis aims at a systematic assessment of LTA and PRA.

\section{Methods}

\section{Data sources and search}

We searched MEDLINE, Pubmed, and Embase database and finally obtained 19 studies published since January 2009.Systematic review was conducted based on the Preferred Reporting Items for Systematic Reviews and Meta-analyses. The following keywords were used:"transperitoneal","retroperitoneal",and "adrenalectomy". We also conducted a manual search for related articles from references to identify additional articles. All studies were extracted by two authors separately, and any divergence was resolved through consensus.

\section{Selection criteria}

Inclusion criteria were: (1) Comparison of clinical characteristics and perioperative outcomes of patients with LTA and PRA;(2) studies having full-text and relevant data were included;(3)studies published in English language;(4)All included studies provide the following data: basic characteristics of patients (age, gender [Male/ Female] ,body mass index [BMI], previous abdominal surgery), characteristics of tumor (size, side, and type of endocrine disorder), surgical outcomes (operative time, blood loss, time to oral intake, and duration of hospital stay), and postoperative outcomes (total complications, conversion, blood transfusion and mortality). The flow chart of study selection is shown in Figure1.The meta-analyses were based on published researches,so ethical approval was not required for our study.

\section{Quality assessment}

As shown in Figure 2 and Figure 3,Cochrane 'Risk of bias' assessment tool was used for quality assessment in this meta-analysis. Evaluation based on:A:Sequence generation;B:Allocation concealment;C: Blinding of participants,personnel;D: Blinding of outcome assessment;E:Incomplete outcome data;F:Selective reporting;G: Other sources of bias.All authors were involved in the quality assessment of articles included, and any divergence was resolved through consensus.Finally everyone agreed on the quality assessment.

\section{Statistical analyses}


RevMan 5.3(Cochrane Collaboration) ${ }^{[8]}$ was used for data analysis.Variables were pooled only when more than 3 studies were evaluated.The odds ratio(OR) and the corresponding $95 \%$ confidence interval $[\mathrm{Cl}]^{[8]}$ were used to assess the differences. We considered the study present significant heterogeneity if $\mathrm{P} \mathbb{}$ 0.05.Statistical heterogeneity was measured with the $\mathrm{I}^{2}$ statistic. The random-effects model was used when $\mathrm{I}^{2} \varangle 50 \%$.

If original articles did not provide means and standard deviations (SDs) or we did not get the data we needed from authors, we used median, range, and sample size to estimate the means and $\mathrm{SDs}^{[9]}$.

\section{Results}

\section{Study Characteristics}

Of 592 retrieved studies, 573 articles were excluded for different reasons.Finally, 19 studies ${ }^{[10-28]}$ were included in our analysis.Table 1 lists the basic characteristics of the included studies in the meta-analysis,and Table 2 shows the clinical and pathologic characteristics of the included studies. The two groups were similar in age (MD $-4.03,95 \% \mathrm{Cl}-8.82$ to $0.76, \mathrm{P}=0.10), \mathrm{BMI}(\mathrm{MD} 0.17,95 \% \mathrm{Cl}-0.53$ to $0.87, \mathrm{P}=0.64)$, proportion of right sided (OR $0.91,95 \% \mathrm{Cl}$ 0.74 to $1.12, \mathrm{P}=0.35$ ), proportion of bilateral lesions (OR $1.21,95 \% \mathrm{Cl} 0.52$ to $2.80, \mathrm{P}=0.65$ ), and previous abdominal surgery (OR $0.91,95 \% \mathrm{Cl} 0.59$ to $1.43, \mathrm{P}$ $=0.70)$, as shown in Fig.4A-E.

The heterogeneity between the two groups was slightly higher in proportion of male patients (OR $0.87,95 \% \mathrm{Cl} 0.78$ to $0.97, \mathrm{P}=0.01)$ (Fig.4F);in addition,the tumor in the PRA group was slightly smaller (MD 0.62, 95\% Cl 0.16 to $1.08, \mathrm{P}=0.008$ ) (Fig.4G).

The pathologic characteristics of patients(Cushing's syndrome (OR $1.16,95 \% \mathrm{Cl} 0.79$ to $1.71, \mathrm{P}=0.46$ ), primary aldosteronism (OR $0.67,95 \% \mathrm{Cl} 0.47$ to $0.94, \mathrm{P}$ $=0.02$ ), pheochromocytoma ( $\mathrm{OR} 1.09,95 \% \mathrm{Cl} 0.79$ to $1.51, \mathrm{P}=0.59)$, and nonfunctioning tumor (OR $1.05,95 \% \mathrm{Cl} 0.75$ to $1.48, \mathrm{P}=0.76)$ ) and proportion of malignant tumor (OR 1.11, 95\% $\mathrm{Cl} 0.64$ to $1.92, \mathrm{P}=0.72$ ) are shown in Table 3 (Fig7A-E).

\section{Comparison of surgical outcomes between LTA and PRA}

\section{Operative time}

18 studies including 1663 patients were pooled to evaluate operative time. The heterogeneity among studies was high $\left(P<0.00001, I^{2}=95 \%\right)$. The $P R A$ group was associated with a significantly shorter operative time (MD 17.54, 95\% Cl 9.67to 25.40, P < 0.0001) (Fig.5A).

\section{Blood loss}

14 studies including 1168 patients were pooled to evaluate blood loss.Significant heterogeneity was shown among studies $\left(\mathrm{P}<0.00001, \mathrm{I}^{2}=97 \%\right)$. The results showed greater estimated blood loss in the LTA group with a random-effects model(MD 37.75, 95\% Cl 18.08 to 57.41, P = 0.0002) (Fig.5B).

\section{Hospital stay}

16 studies including 1466 patients were pooled to evaluate hospital stay. Length of hospital stay was significantly less in the PRA group (MD 1.19 , 95\% Cl 0.76 to 1.63 , $P<0.00001$ ) (Fig.5C).

\section{Time to first oral intake}

6 studies including 521 patients were pooled to evaluate time to first oral intake. The results showed a significantly shorter time to first oral intake in the PRA group(MD 0.48, 95\% Cl 0.11 to $0.86, \mathrm{P}=0.01$ ) (Fig.5D).

\section{Postoperative outcomes}

Results of postoperative complications were shown in Table 3.There was no statistical significance between LTA and PRA for overall complication(OR 1.37, $95 \% \mathrm{Cl} 0.96$ to $1.97, \mathrm{P}=0.08$ ) (Fig.6A), conversion to open laparotomy(OR 1.16, 95\% $\mathrm{Cl} 0.63$ to $2.16, \mathrm{P}=0.63$ ) (Fig.6B) or blood transfusion(OR 2.22, 95\% Cl 0.51 to $9.57, \mathrm{P}=0.28$ ) (Fig.6C). Only Two patients in the LTA group (Berber et al ${ }^{19}$ ) died postoperatively from cardiac and pulmonary causes. No mortality was encountered in PRA group.

\section{Discussion}

Laparoscopic adrenalectomy has become an accepted surgical procedure world wide for adrenal gland disease.Despite LTA has advantages of wide surgical space and familiarity of anatomy,PRA are equally effective and safe because of the superiority of direct approach to adrenal lesions ${ }^{[6,21,22]}$.Besides,PRA,which can avoid injury to abdominal organs ${ }^{[29]}$,perhaps should be preferred for patients with a history of abdominal surgery and in bilateral adrenal lesions.

Although numerous reports have identified PRA seems more desirable compared with LTA,most of them have the disadvantage of small sample size or stringent inclusion criteria in a single-institution. To overcome these limitations, we performed this meta-analysis.Although no difference was shown in most clinical characteristics (age, BMI, proportion of right sided, proportion of bilateral lesions, and previous abdominal surgery),the heterogeneity was found in the proportion of male patients and size of the tumor between 2 groups. Both procedures were confirmed the safety and efficacy.The results showed PRA has more advantages over LTA,such as shorter operative time, lower estimated blood loss, shorter hospital stay and shorter time to first oral intake. The meta- 
analysis showed that there were no statistically significance between LTA and PRA in terms of postoperative outcomes(total complications, conversion rates and blood transfusion).

Rates of conversion to laparotomy of LTA and PRA were 3.1\% (23/753) and 2.6\% (16/614), respectively.And the reasons for conversion were different. Conversion occurred in LTA due to the large tumor (which could not be separated safely from the undersurface of the liver laparoscopically), extensive adhesions from prior abdominal surgery,and malignancy with renal vasculature;Whereas the reason of conversion in RLA are uncontrolled bleeding, adhesions by intraoperatively suspected malignant pheochromocytoma, secondary adrenal metastases with invasion, a large primary tumor and inadequate visualization, BMI of 40 had failure to progress, and inability to maintain adequate retroperitoneal insufflation due to a small tear in the peritoneum.

Complications occurred in both groups. The reported complications in LTA included episode of postoperative pneumonia,symptomatic port-site incisional hernia, colon injury,spleen injury, a pulmonary embolism,symptomatic atrial fibrillation, pneumothorax, and hematoma. The complication in RLA included neuromuscular pain (which was temporary in most patients),peritoneum injury,pleura injury, retroperitoneal hematoma, permanent blindness(unexplained thromboembolism to the retinal artery).

There were certain limitations in our analysis:the 10-year study may results in the risk of potential confounding variables and biases. In addition,the higher heterogeneity was found in the size of the tumor, which demonstrate PRA perhaps superior in smaller tumours. Further studies are needed to confirm the results of larger adrenal tumors.

\section{Conclusions}

This meta-analysis suggests that PRA has more advantages over LTA,such as shorter operative time,lower estimated blood loss,shorter hospital stay and shorter time to first oral intake.And there were no statistically significance between LTA and PRA in terms of postoperative outcomes(total complications, conversion rates and blood transfusion).

\section{Abbreviations}

LTA:lateral transperitoneal adrenalectomy; PRA: posterior retroperitoneal adrenalectomy BMI:body mass inde ;MD:Mean difference;OR:odds ratio;SD:standard deviation; Cl:confidence interval;CT:computed tomography;NA:not available

\section{Declarations}

\section{Ethics approval and consent to participate}

All analyses were based on previous published studies, thus no ethical approval and patient consent are required.

\section{Consent for publication}

Not applicable.

\section{Availability of data and materials}

The datasets used and/or analysed during the current study available from the corresponding author on reasonable request.

\section{Competing interests}

The authors declare that they have no competing interests.

\section{Funding}

LYY, LQ, and LL performed the data extraction, carried out the meta-analysis and drafted the paper.LYY was funded by Natural Science Foundation of Shandong Province(ZR2017LH016), Yantai Science and Technology Bureau(2018SFGY117).

The funding agencies had no role in this meta-analysis.

\section{Authors'contributions}

WHT designed the research, interpreted the data and revised the paper. LYY, LQ, and LL performed the data extraction,data analysis and review of drafts. All authors read and approved the final manuscript.

\section{Acknowledgements}

Not applicable.

\section{References}

[1] Conzo G, Tartaglia E, Gambardella C, Esposito D, Sciascia V, Mauriello C, Nunziata A, Siciliano G, Izzo G, Cavallo F, Thomas G, Musella M, Santini L: Minimally invasive approach for adrenal lesions: Systematic review of laparoscopic versus retroperitoneoscopic adrenalectomy and assessment of risk 
factors for complications.

[2] Buia A, Stockhausen F, Hanisch E. Laparoscopic surgery: a qualified systematic review. World J Methodol. 2015;5:238-54.

[3]Gagner M, Lacroix A, Bolte E. Laparoscopic adrenalectomy in Cushing's syndrome and pheochromocytoma. N Engl J Med. 1992;327:1033.

[4] Frezza EE, Ikramuddin S, Gourash W, Schauer P: Laparoscopic resection of a large periadrenal nonmalignant pheochromocytoma.Surg Endosc 2002, 16, $362-363$.

[5]Mercan S,Seven R,Ozarmagan S et al.Endoscopic retroperitoneal adrenalectomy.Surgery 1995;118:1071-5.

[6] Walz MK, Alesina PF, Wenger FA, Koch JA, Neumann HP, Petersenn S, Schmid KW, Mann K: Posterior retroperitoneoscopic adrenalectomy - results of 560 procedures in 520 patients. Surgery 2006, 30, 899-908.

[7]Shen WT, Grogan R, Vriens M, et al. One hundred two patients with pheochromocytoma treated at a single institution since the introduction of laparoscopic adrenalectomy. Arch Surg. 2010;145:893-7.

[8]DerSimonian R,Laird N. Meta-analysis in clinical trials. Control Clin Trials.1986;7(3):177-88.

[9]Hozo SP, Djulbegovic B, Hozo I. Estimating the mean and variance from the median, range, and the size of a sample. BMC Medical Research Methodology 2005;5:13.

[10]Kozłowski T, Choromanska B, Wojskowicz P, Astapczyk K, Łukaszewicz J, Rutkowski D, Dadan J, Rydzewska-Rosołowska A, Myśliwiec P. Laparoscopic adrenalectomy: lateral transperitoneal versus posterior retroperitoneal approach - prospective randomized trial. Wideochir Inne Tech Maloinwazyjne. 2019 Apr;14(2):160-169. doi: 10.5114/wiitm.2019.84694. Epub 2019 May 5. PMID: 31118978; PMCID: PMC6528120.

[11] Chai YJ, Yu HW, Song RY, Kim SJ, Choi JY, Lee KE. Lateral transperitoneal adrenalectomy versus posterior retroperitoneoscopic adrenalectomy for benign adrenal gland disease: randomized controlled trial at a single tertiary medical center. Annals of Surgery 2019;269:842-848.

[12]Shiraishi, K; Kitahara, S; Ito, H; Matsuyama, H;et al.Transperitoneal versus retroperitoneal laparoscopic adrenalectomy for large pheochromocytoma: Comparative outcomes.Int J Urol.2019 02 ;26(2):212-216.

[13]Chen W, Liang Y, Lin W, Fu GQ, Ma ZW. Surgical management of large adrenal tumors: impact of different laparoscopic approaches and resection methods on perioperative and long-term outcomes. BMC Urol. 2018 May 8;18(1):31. doi: 10.1186/s12894-018-0349-0. PMID: 29739388; PMCID: PMC5941476.

[14]Wessel M.C.M. Vorselaars, et al., Hemodynamic instability during surgery for pheochromocytoma: comparing the transperitoneal and retroperitoneal approach in a multicenter analysis of 341 patients, Surgery (2017), doi: 10.1016/j.surg.2017.05.029

[15]M. Marek-Safiejko et al.A Comparison of Two Approaches to Laparoscopic Adrenalectomy: Lateral Transperitoneal Versus Posterior Retroperitoneal Approach.Adv Clin Exp Med 2016, 25, 5, 829-835.

[16]Terry C. Lairmore,Jessica Folek,Cara M. Govednik, Samuel K. Snyder.Improving Minimally Invasive Adrenalectomy: Selection of Optimal Approach and Comparison of Outcomes.World J Surg.2016;40(7):1625-31.

[17]Chiang Po Hui Chiang PH,Yu CJ,Lee WC,Wang HJ,Hsu WC.Comparison of Retroperitoneoscopic and Transperitoneal Laparoscopic Adrenalectomy for Right-Sided Benign Tumors: A Single-Institute Experience.Urol Int 2015;94:144-148.

[18]Barczynski M, Konturek A, Nowak W. Randomized clinical trial of posterior retroperitoneoscopic adrenalectomy versus lateral transperitoneal laparoscopic adrenalectomy with a 5-year follow-up. Annals of Surgery 2014;260:740-7.

[19]Cabalag M. S., Mann G. B., Gorelik A., Miller J. A. Comparison of outcomes after laparoscopic versus posterior retroperitoneoscopic adrenalectomy: a pilot study. Surgical Laparoscopy, Endoscopy \& Percutaneous Techniques. 2014;24(1):62-66.

[20]Mohammadi-Fallah MR, Mehdizadeh A, Badalzadeh A, Izadseresht B, Dadkhah N, Barbod A. Comparison of transperitoneal versus retroperitoneal laparoscopic adrenalectomy in a prospective randomized study. Journal of Laparoendoscopic \& Advanced Surgical Techniques. Part A 2013;23:342-6.

[21]Constantinides V. A., Christakis I., Touska P., Meeran K., Palazzo F. Retroperitoneoscopic or laparoscopic adrenalectomy? A single-centre UK experience. Surgical Endoscopy. 2013;27(11):4147-4152.

[22]Lee C. R., Walz M. K., Park S., Park J. H., Jeong J. S., Lee S. H., Kang S.-W., Jeong J. J., Nam K.-H., Chung W. Y., Park C. S. A comparative study of the transperitoneal and posterior retroperitoneal approaches for laparoscopic adrenalectomy for adrenal tumors. Annals of Surgical Oncology. 2012;19(8):26292634.

[23]Miccoli P,Materazzi G,Brauckhoff M,Ambrosini CE,Miccoli M,Dralle H.No Outcome Differences between a Laparoscopic and Retroperitoneoscopic Approach in Synchronous Bilateral Adrenal Surgery.World J Surg (2011) 35:2698-2702.

[24]Ramacciato G, Nigri GR, Petrucciani N, Di Santo V, Piccoli M, Buniva P, et al. Minimally invasive adrenalectomy: a multicenter comparison of transperitoneal and retroperitoneal approaches. Am Surg 2011;77:409-16.

Page 5/14 
[25]Kiriakopoulos A., Economopoulos K. P., Poulios E., Linos D. Impact of posterior retroperitoneoscopic adrenalectomy in a tertiary care center: a paradigm shift. Surgical Endoscopy. 2011;25(11):3584-3589.

[26]Dickson P. V., Alex G. C., Grubbs E. G., Ayala-Ramirez M., Jimenez C., Evans D. B., Lee J. E., Perrier N. D. Posterior retroperitoneoscopic adrenalectomy is a safe and effective alternative to transabdominal laparoscopic adrenalectomy for pheochromocytoma. Surgery. 2011;150(3):452-458.

[27]Li QY, Li F. Laparoscopic adrenalectomy in pheochromocytoma: retroperitoneal approach versus transperitoneal approach. J Endourol 2010;24:1441-5.

[28]Berber E, Tellioglu G, Harvey A, Mitchell J, Milas M, Siperstein A. Comparison of laparoscopic transabdominal lateral versus posterior retroperitoneal adrenalectomy. Surgery 2009;146:621-5.

[29] Walz M. K., Peitgen K., Hoermann R., Giebler R. M., Mann K., Eigler F. W. Posterior retroperitoneoscopy as a new minimally invasive approach for adrenalectomy: results of 30 adrenalectomies in 27 patients. World Journal of Surgery. 1996;20(7):769-774.

\section{Tables}

Table 1.Characteristics of the included studies 


\begin{tabular}{|c|c|c|c|c|c|c|c|c|}
\hline \multirow[t]{2}{*}{ Author } & \multirow[t]{2}{*}{ Year } & \multirow[t]{2}{*}{ Country } & \multirow[t]{2}{*}{ Type of study } & \multirow{2}{*}{$\begin{array}{l}\text { Trial } \\
\text { period }\end{array}$} & \multirow[t]{2}{*}{ Inclusion criteria } & \multirow[t]{2}{*}{ Exclusion criteria } & \multicolumn{2}{|c|}{ Sample } \\
\hline & & & & & & & LTA & PRA \\
\hline Kozlowski et al ${ }^{10}$ & 2019 & Poland & $\begin{array}{l}\text { Prospective } \\
\text { randomized }\end{array}$ & $\begin{array}{l}2015.2- \\
2018.6\end{array}$ & $\begin{array}{l}\text { size of the adrenal tumor for } \\
\text { planned unilateral } \\
\text { adrenalectomy up to } 8 \mathrm{~cm}\end{array}$ & $\begin{array}{l}\text { tumors }>8 \mathrm{~cm} \text {, imaging } \\
\text { features suggesting primary } \\
\text { invasive malignant tumors and } \\
\text { refusal of the patient to } \\
\text { undergo randomization }\end{array}$ & 33 & 44 \\
\hline Chai et al ${ }^{11}$ & 2019 & Korea & $\begin{array}{l}\text { Prospective } \\
\text { randomized }\end{array}$ & $\begin{array}{l}2012.9- \\
2016.2\end{array}$ & $\begin{array}{l}\text { unilateral benign } \\
\text { tumor,BMl } \leq 35 \mathrm{~kg} / \mathrm{m}^{2}, \text { age } \geq 18 \\
\text { and age }<80 \text {,tumor size }<7 \mathrm{~cm} \\
\text { in maximal diameter on } \\
\text { preoperative CT scan }(<5 \mathrm{~cm} \\
\text { for pheochromocytoma),no } \\
\text { history of abdominal surgery } \\
\text { in the same quadrant of } \\
\text { adrenal tumor location, and } \\
\text { normal cognitive function. }\end{array}$ & $\begin{array}{l}\text { necessity of additional surgical } \\
\text { procedure,pregnancy,ongoing } \\
\text { infection,uncontrolled } \\
\text { hypertension,or a history of } \\
\text { coronary heart disease (CHD), } \\
\text { or cerebrovascular disease } \\
\text { (CVD) }\end{array}$ & 42 & 41 \\
\hline Shiraishi et al ${ }^{12}$ & 2019 & Japan & $\begin{array}{l}\text { Retrospective, } \\
\text { non- } \\
\text { randomized }\end{array}$ & $\begin{array}{l}2008.1- \\
2017.12\end{array}$ & Pheochromocytomas $>5 \mathrm{~cm}$ & Not specified & 12 & 10 \\
\hline $\begin{array}{l}\text { WeiChen } \\
\text { et } \mathrm{al}^{13}\end{array}$ & 2018 & China & retrospective & $\begin{array}{l}2011.1- \\
2015.6\end{array}$ & $\begin{array}{l}\text { (i) the patient was confirmed } \\
\text { as having an adrenal tumor } \\
\text { by imaging examination and } \\
\text { underwent minimally invasive } \\
\text { surgery treatment, (ii) the } \\
\text { baseline indicators and } \\
\text { perioperative parameters were } \\
\text { completely recorded, and (iii) } \\
\text { a large adrenal tumor was } \\
\text { defined as an adrenal tumor } \\
\text { with a diameter larger than } \\
5 \mathrm{~cm} \text {. }\end{array}$ & $\begin{array}{l}\text { (i) there were no measurable } \\
\text { data reported, (ii) the tumor was } \\
\text { operated on via open surgery, } \\
\text { and (iii) a hand-assisted } \\
\text { laparoscopic method was } \\
\text { adopted during the surgery. }\end{array}$ & 37 & 41 \\
\hline Vorselaars et al ${ }^{14}$ & 2018 & $\begin{array}{l}\text { Europe, } \\
\text { America, } \\
\text { Canada }\end{array}$ & $\begin{array}{l}\text { Retrospective } \\
\text { non- } \\
\text { randomized }\end{array}$ & $\begin{array}{l}2000- \\
2016\end{array}$ & $\begin{array}{l}\text { All consecutive patients with } \\
\text { pheochromocytoma who } \\
\text { underwent unilateral } \\
\text { laparoscopic adrenalectomy }\end{array}$ & $\begin{array}{l}\text { patients with } \\
\text { open,partial,bilateral,or } \\
\text { converted procedures }\end{array}$ & 240 & 101 \\
\hline $\begin{array}{l}\text { Marek-Safiejko et } \\
\text { al }{ }^{15}\end{array}$ & 2016 & Poland & retrospective & $\begin{array}{l}2010.2- \\
2015.2\end{array}$ & Not specified & $\begin{array}{l}\text { All patients with suspected } \\
\text { adrenal carcinoma or a tumor } \\
\text { larger than } 10 \mathrm{~cm} \text { were qualified } \\
\text { for the conventional method }\end{array}$ & 27 & 77 \\
\hline 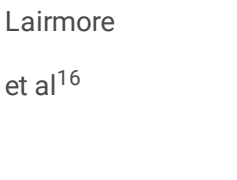 & 2016 & Thailand & retrospective & $\begin{array}{l}2005.1- \\
2015.4\end{array}$ & Not specified & $\begin{array}{l}\text { Primary malignant adrenal } \\
\text { tumors, and tumors not felt to } \\
\text { be amenable to a minimally } \\
\text { invasive approach } \\
\text { (generally }>8.0 \mathrm{~cm} \text { ) were } \\
\text { excluded. }\end{array}$ & 67 & 76 \\
\hline $\begin{array}{l}\text { Chiang } \\
\text { et al }{ }^{17}\end{array}$ & 2015 & Taiwan & $\begin{array}{l}\text { Retrospective, } \\
\text { nonrandomized }\end{array}$ & $\begin{array}{l}2000.3- \\
2011.9\end{array}$ & Not specified & $\begin{array}{l}\text { Adrenocortical malignancies } \\
\text { were excluded }\end{array}$ & 24 & 31 \\
\hline $\begin{array}{l}\text { Barczynski et } \\
\text { al }^{18}\end{array}$ & 2014 & Poland & $\begin{array}{l}\text { Prospective, } \\
\text { randomized }\end{array}$ & $\begin{array}{l}2006.1- \\
2008.6\end{array}$ & $\begin{array}{l}\text { unilateral adrenal surgery for } \\
\text { a benign tumor up to } 7 \mathrm{~cm} \text { in } \\
\text { diameter }\end{array}$ & $\begin{array}{l}\text { diffuse peritonitis in history, } \\
\text { major abdominal surgery in } \\
\text { history, planned bilateral } \\
\text { adrenal surgery, adrenal tumor } \\
\text { more than } 7 \mathrm{~cm} \text { in } \\
\text { diameter,suspected } \\
\text { adrenocortical cancer, } \\
\text { metastasis to adrenal } \\
\text { gland,previous adrenal surgery, } \\
\text { pregnancy or lactation, age less } \\
\text { than } 18 \text { or more than } 80 \\
\text { years,American Society of } \\
\text { Anesthesiologists fitness grade } \\
\text { IV, and inability to comply with } \\
\text { the follow-up protocol }\end{array}$ & 32 & 33 \\
\hline $\begin{array}{l}\text { Cabalag } \\
\text { et al }\end{array}$ & 2014 & Australia & $\begin{array}{l}\text { Retrospective } \\
\text { Nonrandomized }\end{array}$ & $\begin{array}{l}2009.10- \\
2011.12\end{array}$ & $\begin{array}{l}\text { functional tumors }<8 \mathrm{~cm} \\
\text { without signs of local } \\
\text { invasion, nonfunctional } \\
\text { tumors between } 4 \text { and } 8 \mathrm{~cm} \text {, } \\
\text { or }<4 \mathrm{~cm} \text { with suspicious } \\
\text { features on preoperative } \\
\text { imaging,and solitary } \\
\text { metastasis to the adrenal. }\end{array}$ & Not specified & 13 & 10 \\
\hline $\begin{array}{l}\text { Mohammadi- } \\
\text { Fallah et al }{ }^{20}\end{array}$ & 2013 & Iran & Prospective, & $\begin{array}{l}2008.9- \\
2011.11\end{array}$ & Not specified & $\begin{array}{l}\text { patients with morbid obesity } \\
\left(\mathrm{BMl}>40 \mathrm{~kg} / \mathrm{m}^{2}\right) \text {, prior major }\end{array}$ & 11 & 13 \\
\hline
\end{tabular}

Page 7/14 


\begin{tabular}{|c|c|c|c|c|c|c|c|c|}
\hline & & & randomized & & & $\begin{array}{l}\text { abdominal surgery,clinical } \\
\text { suspicion of malignancy,tumor } \\
\text { size }>6 \mathrm{~cm} \text {,and bilateral } \\
\text { adrenalectomy }\end{array}$ & & \\
\hline $\begin{array}{l}\text { Constantinides et } \\
\mathrm{al}^{21}\end{array}$ & 2013 & UK & prospectively & $\begin{array}{l}2010.9- \\
2012.9\end{array}$ & $\begin{array}{l}\text { All adult patients undergoing } \\
\text { unilateral adrenalectomy via a } \\
\text { minimally invasive approach } \\
\text { were eligible for inclusion in } \\
\text { the study irrespective of } \\
\text { surgical indication }\end{array}$ & $\begin{array}{l}\text { Patients undergoing open } \\
\text { adrenalectomy, bilateral adrenal } \\
\text { surgery,or paraganglioma } \\
\text { resection were excluded }\end{array}$ & 36 & 35 \\
\hline $\begin{array}{l}\text { Lee,CR } \\
\text { et } \mathrm{al}^{22}\end{array}$ & 2012 & $\begin{array}{l}\text { Not } \\
\text { specified }\end{array}$ & retrospective & $\begin{array}{l}2009.1- \\
2010.7\end{array}$ & Not specified & bilateral pheochromocytoma & 26 & 17 \\
\hline $\begin{array}{l}\text { Miccoli } \\
\text { et } \mathrm{al}^{23}\end{array}$ & 2011 & $\begin{array}{l}\text { Italy } \\
\text { Germany }\end{array}$ & retrospective & $\begin{array}{l}1994- \\
2008\end{array}$ & $\begin{array}{l}\text { underwent bilateral } \\
\text { synchronous adrenalectomy }\end{array}$ & Not specified & 20 & 14 \\
\hline $\begin{array}{l}\text { Ramacciato et } \\
\mathrm{al}^{24}\end{array}$ & 2011 & Italy & $\begin{array}{l}\text { nonrandomized, } \\
\text { retrospective }\end{array}$ & $\begin{array}{l}1995- \\
2009\end{array}$ & Not specified & Not specified & 127 & 44 \\
\hline $\begin{array}{l}\text { Kiriakopoulos et } \\
\text { al } 25\end{array}$ & 2011 & Greece & $\begin{array}{l}\text { Prospective } \\
\text { nonrandomized }\end{array}$ & $\begin{array}{l}2008.5- \\
2010.9\end{array}$ & Not specified & Not specified & 30 & 30 \\
\hline Dickson et al ${ }^{26}$ & 2011 & America & retrospectively & $\begin{array}{l}2000.5- \\
2009.12\end{array}$ & Not specified & Not specified & 23 & 23 \\
\hline $\begin{array}{l}\mathrm{Li}, \mathrm{QY} \\
\text { et } \mathrm{al}^{27}\end{array}$ & 2010 & China & retrospective & $\begin{array}{l}1999- \\
2008\end{array}$ & $\begin{array}{l}\text { unilateral benign } \\
\text { pheochromocytoma }<6 \mathrm{~cm} \text { in } \\
\text { diameter have undergone LA } \\
\text { for pheochromocytoma }\end{array}$ & $\begin{array}{l}\text { Patients with bilateral } \\
\text { pheochromocytoma or } \\
\text { malignancy }\end{array}$ & 40 & 59 \\
\hline $\begin{array}{l}\text { Berber } \\
\text { et } \mathrm{al}^{28}\end{array}$ & 2009 & America & retrospective & $\begin{array}{l}1994- \\
2008\end{array}$ & Not specified & Not specified & 69 & 90 \\
\hline Total & & & & & & & 909 & 789 \\
\hline
\end{tabular}

LTA:Iateral transperitoneal adrenalectomy;PRA:posterior retroperitoneoscopic adrenalectomy.CT:computed tomography

Table 2.Clinical characteristics 


\begin{tabular}{|c|c|c|c|c|c|c|c|c|c|c|}
\hline \multirow[t]{2}{*}{ Study } & \multirow[t]{2}{*}{ Group } & \multirow{2}{*}{$\begin{array}{l}\text { Tumor } \\
\text { size } \\
, \mathrm{cm} \\
( \pm S D)\end{array}$} & \multirow{2}{*}{$\begin{array}{l}\text { Age, } \\
\text { mean years } \\
( \pm \mathrm{SD})\end{array}$} & \multirow{2}{*}{$\begin{array}{l}\mathrm{BMI}, \mathrm{kg} / \mathrm{m}^{2} \\
( \pm \mathrm{SD})\end{array}$} & \multirow{2}{*}{$\begin{array}{l}\text { Gender } \\
\text { (Male } \\
\text { /female) }\end{array}$} & \multirow{2}{*}{$\begin{array}{l}\text { Tumor } \\
\text { location } \\
\text { (Right/Left } \\
\text { /Bilateral) }\end{array}$} & \multicolumn{4}{|c|}{ Type of endocrine disorder } \\
\hline & & & & & & & Pheocromocytoma & Malignant & $\begin{array}{l}\text { Conn's } \\
\text { disease }\end{array}$ & $\begin{array}{l}\text { Cushing } \\
\text { syndrome }\end{array}$ \\
\hline \multirow{2}{*}{$\begin{array}{l}\text { Kozlowski et } \\
\text { al }^{10}\end{array}$} & LTA & $4.1^{*}$ & $61.2 \pm 8.3$ & $30.1 \pm 6$ & $13 / 20$ & $11 / 22 / 0$ & 4 & 1 & 2 & 5 \\
\hline & PRA & $4.0^{*}$ & $59.3 \pm 10.2$ & $29.1 \pm 5.2$ & $21 / 23$ & $18 / 26 / 0$ & 9 & 3 & 4 & 3 \\
\hline \multirow[t]{2}{*}{ Chai et al ${ }^{11}$} & LTA & $2.9 \pm 1.4$ & $48.0 \pm 11.4$ & $24.2 \pm 3.3$ & $14 / 28$ & $18 / 24 / 0$ & 8 & NA & $20^{\#}$ & 7 \\
\hline & PRA & $3.0 \pm 1.3$ & $46.4 \pm 11.0$ & $23.6 \pm 3.0$ & $15 / 26$ & $18 / 23 / 0$ & 7 & & $16^{\#}$ & 10 \\
\hline \multirow{2}{*}{$\begin{array}{l}\text { Shiraishi et } \\
\text { al }^{12}\end{array}$} & LTA & $6.6^{*}$ & $58.8^{\star}$ & $23.4^{*}$ & $7 / 5$ & $7 / 5 / 0$ & 12 & NA & 0 & 0 \\
\hline & PRA & $7.4^{*}$ & $56.3^{\star}$ & $23.2^{*}$ & $4 / 6$ & $6 / 4 / 0$ & 10 & & 0 & 0 \\
\hline \multirow{2}{*}{$\begin{array}{l}\text { WeiChen et } \\
\text { al }^{13}\end{array}$} & LTA & $5.76 \pm 1.34$ & $47.92 \pm 29.61$ & $23.60 \pm 2.92$ & $23 / 14$ & $10 / 25 / 2$ & 3 & 4 & 20 & NA \\
\hline & PRA & $5.81 \pm 1.17$ & $44.41 \pm 38.90$ & $23.52 \pm 2.46$ & $26 / 15$ & $11 / 29 / 1$ & 5 & 2 & 18 & \\
\hline \multirow{2}{*}{$\begin{array}{l}\text { Vorselaars et } \\
\text { al }{ }^{14}\end{array}$} & LTA & $4.52 \pm 1.94$ & $5.5 \pm 15.4$ & $25.3 \pm 5.3$ & $102 / 138$ & $130 / 110 / 0$ & 240 & NA & 0 & 0 \\
\hline & PRA & $3.4 \pm 1.9$ & $45.3 \pm 17.0$ & $24.0 \pm 3.6$ & $46 / 55$ & $45 / 56 / 0$ & 101 & & 0 & 0 \\
\hline \multirow{2}{*}{$\begin{array}{l}\text { Marek-Safiejko } \\
\text { et al }{ }^{15}\end{array}$} & LTA & $6.1 \pm 2.1$ & $53.6 \pm 11.5$ & $28.8 \pm 4.9$ & $11 / 16$ & $12 / 15 / 0$ & 5 & 4 & 1 & 4 \\
\hline & PRA & $4.6 \pm 1.4$ & $58.8 \pm 10.4$ & $30.4 \pm 3.8$ & $32 / 45$ & $39 / 38 / 0$ & 16 & 4 & 10 & 7 \\
\hline \multirow{2}{*}{$\begin{array}{l}\text { Lairmore et } \\
\text { al }^{16}\end{array}$} & LTA & $3.6 \pm 2.1$ & $53.5^{\star}$ & $32.67^{*}$ & $23 / 43$ & $29 / 38 / 0$ & NA & NA & NA & NA \\
\hline & PRA & $2.38 \pm 1.2$ & $52.9 *$ & $31.23^{*}$ & $36 / 36$ & $36 / 40 / 0$ & & & & \\
\hline \multirow[t]{2}{*}{ Chiang et al ${ }^{17}$} & LTA & $4.6 \pm 0.82$ & $53.3^{*}$ & $25.41^{*}$ & $11 / 13$ & $24 / 0 / 0$ & 3 & NA & 8 & 0 \\
\hline & PRA & $3.5 \pm 1.56$ & $53.15^{\star}$ & $25.07^{*}$ & $17 / 14$ & $31 / 0 / 0$ & 5 & & 12 & 2 \\
\hline \multirow{2}{*}{$\begin{array}{l}\text { Barczynski et } \\
\text { al }^{18}\end{array}$} & LTA & $4.03^{*}$ & $46.6^{\star}$ & $27.3^{\star}$ & $9 / 23$ & $15 / 17 / 0$ & 7 & NA & 7 & 3 \\
\hline & PRA & $3.93^{*}$ & $47.9 *$ & $27.6^{*}$ & $8 / 25$ & $16 / 17 / 0$ & 8 & & 7 & 4 \\
\hline \multirow{2}{*}{$\begin{array}{l}\text { Cabalag et } \\
\text { al }^{19}\end{array}$} & LTA & $3.2^{*}$ & $47^{\star}$ & $28 *$ & $5 / 8$ & $4 / 9 / 0$ & NA & 0 & NA & NA \\
\hline & PRA & $3.5^{\star}$ & $61^{*}$ & $28.9 *$ & $5 / 5$ & $5 / 5 / 0$ & & 1 & & \\
\hline \multirow{2}{*}{$\begin{array}{l}\text { Mohammadi- } \\
\text { Fallah } \\
\text { et al }{ }^{20}\end{array}$} & LTA & $2.92^{*}$ & $42.9 *$ & $26,72^{*}$ & $5 / 6$ & $6 / 5 / 0$ & 2 & NA & $2^{\#}$ & 3 \\
\hline & PRA & $2.63^{\star}$ & $42.23^{\star}$ & $27.46^{*}$ & $5 / 8$ & $8 / 5 / 0$ & 2 & & $1^{\#}$ & 4 \\
\hline \multirow{2}{*}{$\begin{array}{l}\text { Constantinides } \\
\text { et } \mathrm{al}^{21}\end{array}$} & LTA & $4.1 \pm 2.31$ & $49.52 \pm 13.62$ & $26.8 \pm 4.64$ & $15 / 21$ & $18 / 18 / 0$ & 7 & 0 & 10 & 8 \\
\hline & PRA & $2.83 \pm 1.27$ & $49.1 \pm 13.55$ & $29.8 \pm 5.52$ & $13 / 22$ & 19/16/0 & 7 & 0 & 10 & 5 \\
\hline \multirow[t]{2}{*}{ Lee,CR et $\mathrm{al}^{22}$} & LTA & $3.86 \pm 3.83$ & $53.4 \pm 9.9$ & $24.49 \pm 2.61$ & $7 / 19$ & $7 / 18 / 1$ & 8 & NA & $4^{\#}$ & 3 \\
\hline & PRA & $2.64 \pm 1.61$ & $57.4 \pm 13.9$ & $24.99 \pm 3.18$ & $6 / 11$ & $8 / 9 / 0$ & 2 & & $7^{\#}$ & 2 \\
\hline \multirow[t]{4}{*}{ Miccoli et al ${ }^{23}$} & LTA & L64.06* & $48.1^{*}$ & $29.4^{\star}$ & $7 / 13$ & $0 / 0 / 20$ & 4 & NA & 0 & 16 \\
\hline & & R61.1* & & & & & & & & \\
\hline & PRA & L37.4* & $38.9 *$ & $26.3^{\star}$ & $6 / 8$ & $0 / 0 / 14$ & 7 & & 1 & 5 \\
\hline & & $\mathrm{R} 42.8^{*}$ & & & & & & & & \\
\hline \multirow{2}{*}{$\begin{array}{l}\text { Ramacciato et } \\
\mathrm{al}^{24}\end{array}$} & LTA & $4.4 \pm 2.8$ & $51.8 \pm 14.0$ & NA & $52 / 75$ & $63 / 58 / 6$ & 20 & 14 & NA & NA \\
\hline & PRA & $4.8 \pm 1.9$ & $54.3 \pm 12.5$ & & $28 / 16$ & $31 / 13 / 0$ & 8 & 5 & & \\
\hline \multirow{2}{*}{$\begin{array}{l}\text { Kiriakopoulos } \\
\text { et } \mathrm{al}^{25}\end{array}$} & LTA & $4.9^{*}$ & $49.5^{\star}$ & NA & $11 / 19$ & $16 / 14 / 0$ & 6 & 2 & $4^{\#}$ & 18 \\
\hline & PRA & $3.8^{*}$ & $53.0^{*}$ & NA & $9 / 21$ & $10 / 20 / 0$ & 6 & 2 & $4^{\#}$ & 17 \\
\hline Dickson,PV et & LTA & $4.0 \pm 2.2$ & $42.0 \pm 18.1$ & $26.1 \pm 5.4$ & $7 / 16$ & $9 / 13 / 1$ & NA & NA & NA & NA \\
\hline & PRA & $3.3 \pm 1.8$ & $47.3 \pm 16.1$ & $26.2 \pm 6.6$ & $11 / 12$ & $11 / 12 / 0$ & & & & \\
\hline Li,QY et $\mathrm{al}^{27}$ & LTA & $4.5 \pm 0.5$ & $37.51 \pm 5.12$ & $25.5 \pm 5.78$ & $17 / 23$ & $22 / 18 / 0$ & NA & NA & NA & NA \\
\hline & PRA & $4.3 \pm 0.8$ & $36.74 \pm 4.32$ & $26.31 \pm 6.22$ & $25 / 34$ & $34 / 25 / 0$ & & & & \\
\hline
\end{tabular}


*except median." aldosteronism

NA:not available.

Table 3.Clinical characteristics and postoperative outcomes

\begin{tabular}{|lcclll|}
\hline Variable & $\mathrm{N}$ & OR & $95 \% \mathrm{Cl}$ & P value \\
\hline $\begin{array}{l}\text { Type of endocrine disorder } \\
\text { Pheocromocytoma }\end{array}$ & 15 & 1.09 & 0.79 to 1.51 & 0.59 \\
\hline Conn's disease & 14 & 0.67 & 0.47 to 0.94 & 0.02 \\
\hline Cushing syndrome & 11 & 1.16 & 0.79 to 1.71 & 0.46 \\
\hline Nonfunctioning & 9 & 1.05 & 0.75 to 1.48 & 0.76 \\
\hline Malignant & 7 & 1.11 & 0.64 to 1.92 & 0.72 \\
\hline Total complications & 14 & 1.37 & 0.96 to 1.97 & 0.08 \\
\hline Conversion to open rates & 14 & 1.16 & 0.63 to 2.16 & 0.63 \\
\hline Blood transfusion & 7 & 2.22 & 0.51 to 9.57 & 0.28 \\
\hline
\end{tabular}

$\mathrm{Cl}$, Confidence interval; $\mathrm{N}$, number of studies reporting the variable; $\mathrm{OR}$, odds ratio.

\section{Figures}




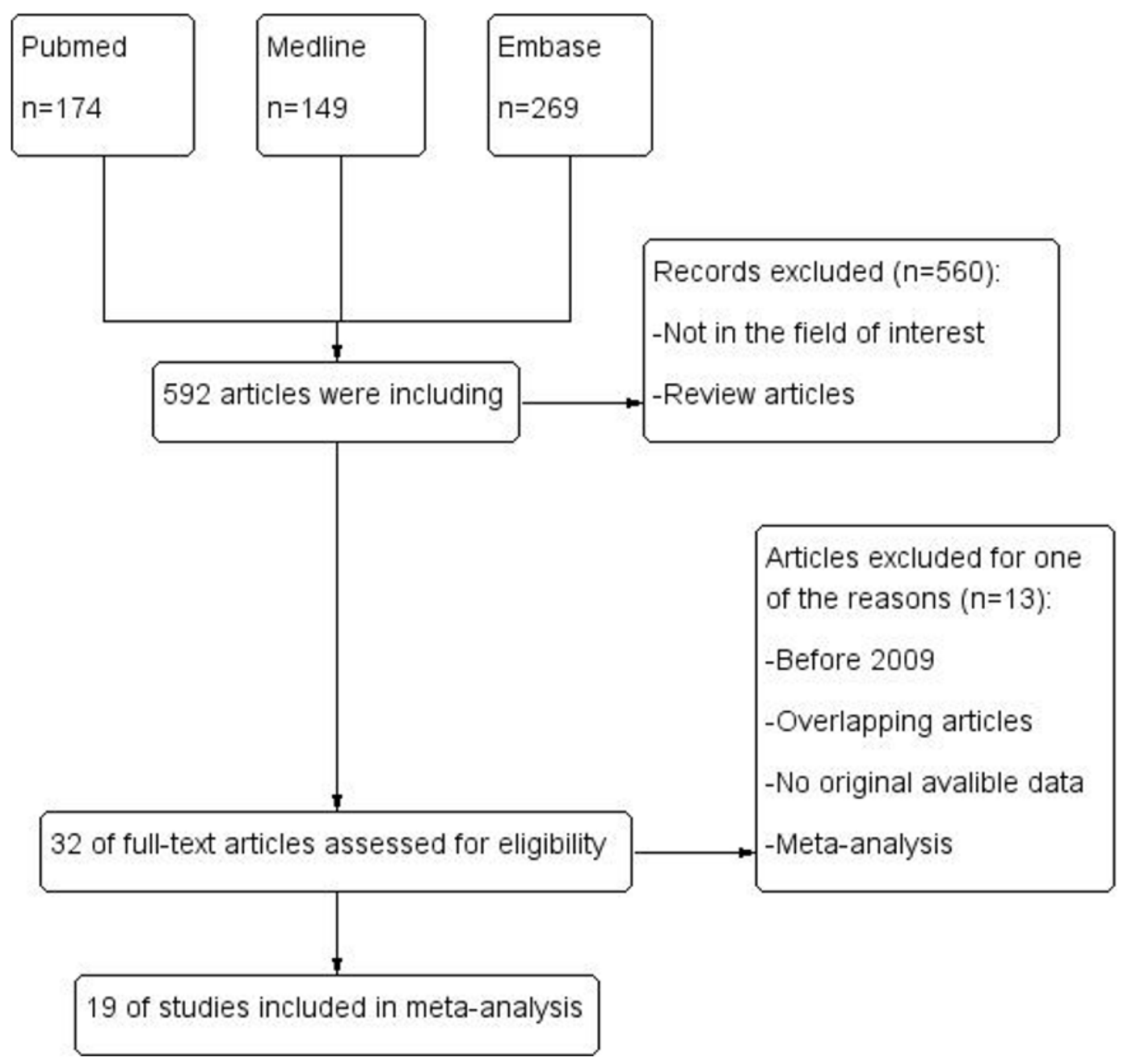

Figure 1

The total flowchart

Random sequence generation (selection bias)

Allocation concealment (selection bias)

Blinding of participants and personnel (performance bias)

Blinding of outcome assessment (detection bias)

Incomplete outcome data (attrition bias)

Selective reporting (reporting bias)

Other bias
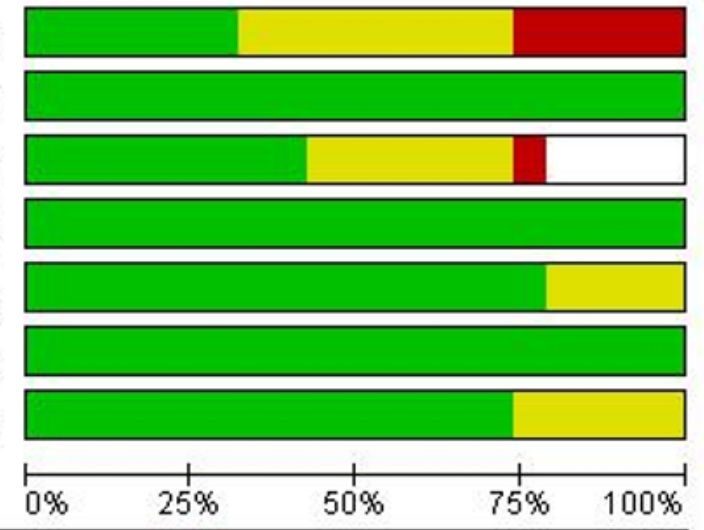

Low risk of bias

Unclear risk of bias

High risk of bias

Figure 2

Risk of bias graph 


\begin{tabular}{|c|c|c|c|c|c|c|c|}
\hline & 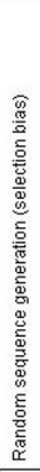 & 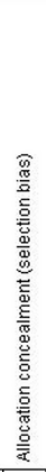 & 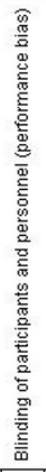 & 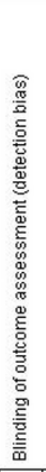 & 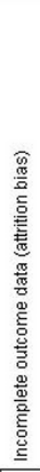 & 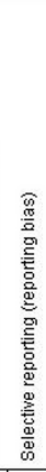 & 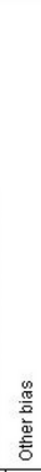 \\
\hline Barczynski 2014 & † & $\odot$ & ๑ & ๑) & $?$ & (†) & ๑ \\
\hline Berber 2009 & $?$ & $\odot$ & (†) & ๑ & $\odot$ & $\odot$ & $\odot$ \\
\hline Cabalag 2014 & 0 & (-) & (-) & † & (†) & (†) & 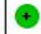 \\
\hline Chai 2019 & $\odot$ & $\odot$ & $?$ & $\odot$ & $?$ & $\odot$ & ? \\
\hline Chiang 2015 & $?$ & $\odot$ & $?$ & ๑ & $\odot$ & (†) & $\odot$ \\
\hline Constantinides 2013 & $?$ & $\odot$ & $?$ & † & † & $\odot$ & $?$ \\
\hline Dickson 2011 & $?$ & (†) & & ๑) & (†) & (†) & † \\
\hline Kiriakopoulos 2011 & 0 & $\odot$ & (†) & $\odot$ & $\odot$ & (†) & ? \\
\hline Kozlowski 2019 & $\odot$ & $\odot$ & 0 & ๑ & $\odot$ & $\odot$ & $\odot$ \\
\hline Lairmore 2016 & $?$ & $\odot$ & $?$ & † & (-) & (†) & ? \\
\hline Lee,CR 2012 & † & $\odot$ & $\odot$ & ๑) & $?$ & (†) & (†) \\
\hline $\mathrm{Li}, Q \mathrm{QY} 2010$ & $?$ & $\odot$ & $?$ & † & $\odot$ & $\odot$ & $\odot$ \\
\hline Marek-Safiejko 2016 & $?$ & $\odot$ & & ๑ & (-) & († & $\odot$ \\
\hline Miccoli 2011 & $\odot$ & $\odot$ & ๑) & ๑) & $?$ & ๑ & $\odot$ \\
\hline Mohammadi-Fallah 2013 & (†) & (†) & (๑) & ๑ & ๑) & (૯) & $\odot$ \\
\hline Ramacciato 2011 & 0 & (†) & $?$ & † & † & $\odot$ & (†) \\
\hline Shiraishi 2019 & - & ๑) & & ๑ & ๑) & (†) & $\odot$ \\
\hline Vorselaars 2018 & 0 & $\odot$ & & ๑ & $\odot$ & († & ? \\
\hline Weichen 2018 & $?$ & • & $\odot$ & ๑ & $\odot$ & († & + \\
\hline
\end{tabular}

\section{Figure 3}

Risk of bias summary 

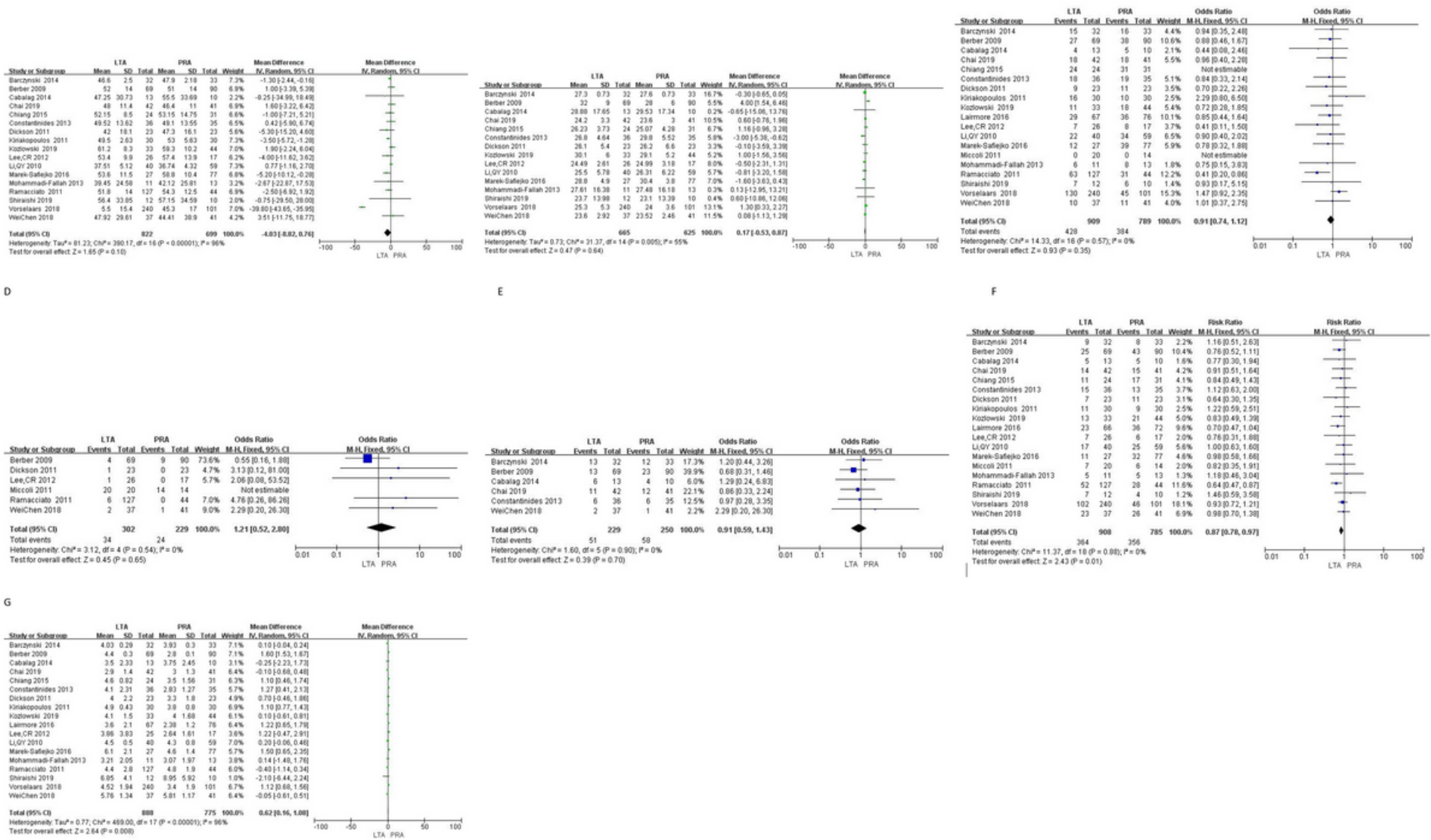

\section{Figure 4}

Forest plots showing changes/numbers in (A) age; (B) BMl; (C) proportion of right side; (D) proportion of bilateral side; (E) previous abdominal surgery; ( $F$ ) proportion of male; (G)tumor size; SD, standard deviation; IV, inverse variance; $\mathrm{M}-\mathrm{H}$, Mantel-Haenszel;Cl, confidence interval; df, degrees of freedom.
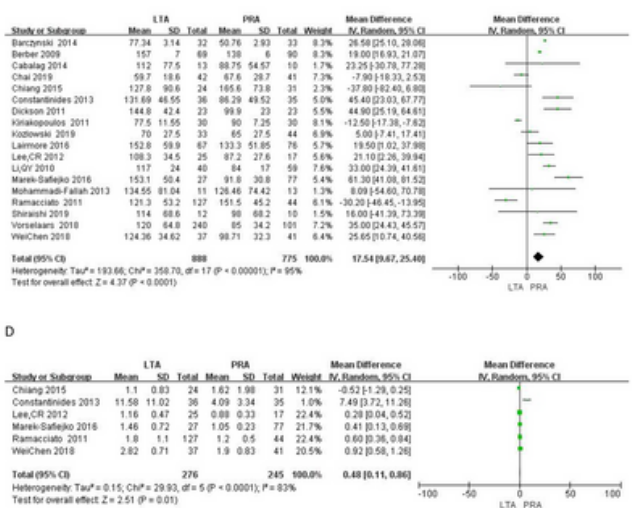

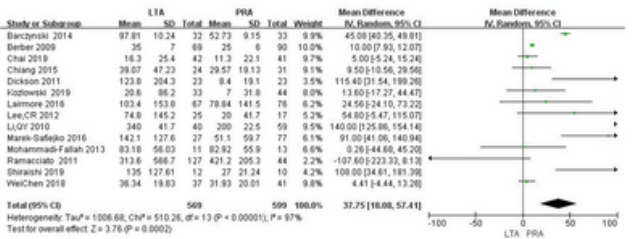

$\mathrm{C}$

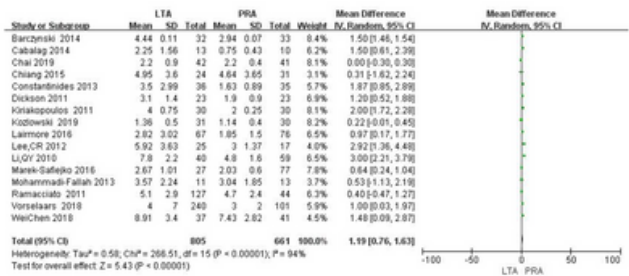

\section{Figure 5}

Forest plots showing changes in(A) operative time; (B) Blood loss; (C) hospital day; (D) time to oral intake;SD, standard deviation; IV, inverse variance; Cl, confidence interval; $\mathrm{df}$, degrees of freedom.

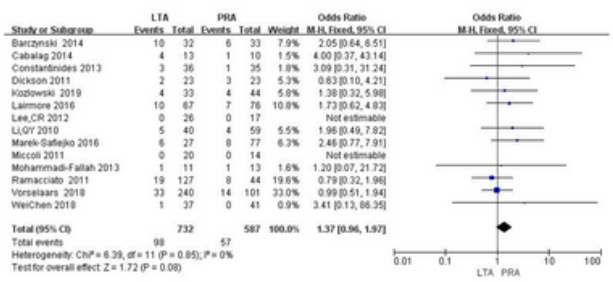

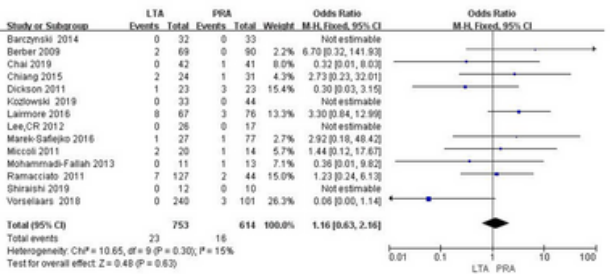

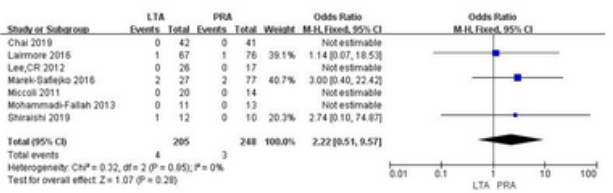


Figure 6

Forest plots showing changes/numbers in(A) Overall complication; (B) conversion; (C) blood transfusion; M-H, Mantel-Haenszel; $\mathrm{Cl}$, confidence interval; df, degrees of freedom.
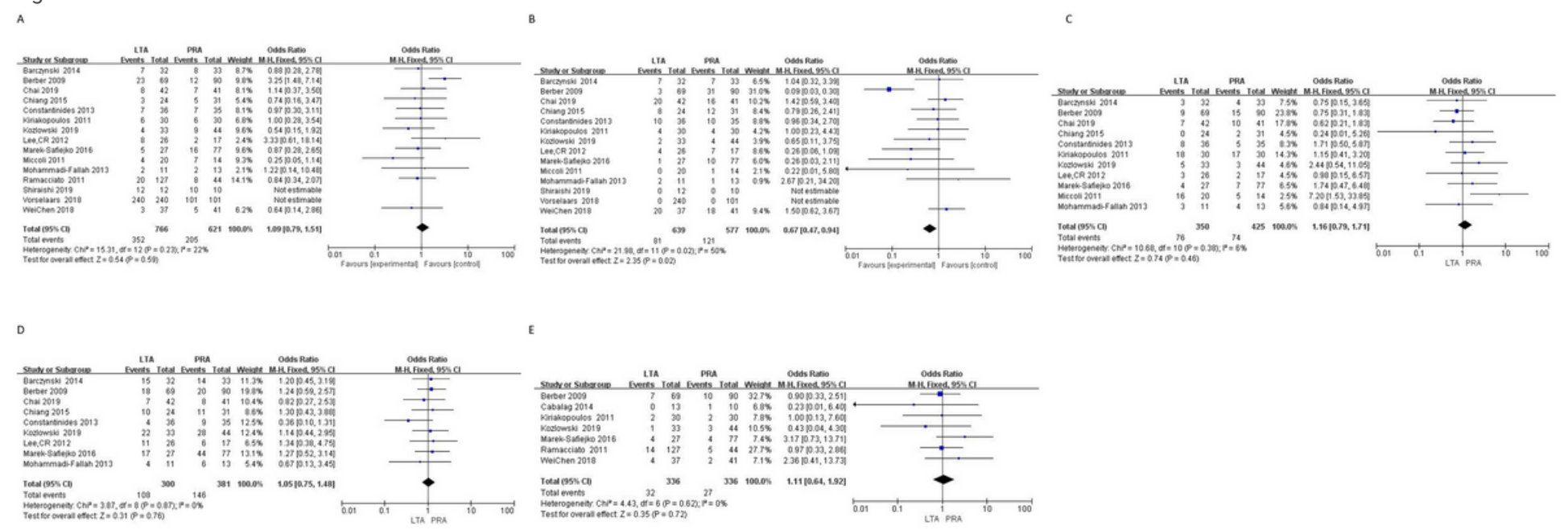

\section{Figure 7}

Forest plots showing changes/numbers in(A) pheocromocytoma; (B) Conn's disease; (C) Cushing syndrome; (D) nonfunctioning;(E) malignant;M-H, MantelHaenszel; $\mathrm{Cl}$, confidence interval; $\mathrm{df}$, degrees of freedom.

\section{Supplementary Files}

This is a list of supplementary files associated with this preprint. Click to download.

- PRISMA2009checklist.doc 